\title{
Twórczość Polaków na Wyspach Brytyjskich. Transnarodowy zwrot w polskiej literaturze
}

Joanna Kosmalska

TEKSTY DRUGIE 2016, NR 3, S. 165-186

DOl $10.18318 /$ td.2016.3.10

Dowieść Madame Mephisto A.M. Bakalar, polskiej migrantki mieszkającej w Londynie, została nominowana w popularnym brytyjskim konkursie literackim do Guardian First Book Award w lipcu 2012 roku. W jednym ze swoich artykułów pisarka podkreśla, że „znakiem naszych czasów jest życie pomiędzy krajami, które pozwala migrantom czerpać to, co najlepsze z obu światów"1. Dwa lata później, w listopadzie 2014 roku, Daniel Żuchowski, polski nauczyciel mieszkający w Dublinie, został zaproszony do zaprezentowania swojego niedawno wydanego zbioru opowiadań The New Dubliners podczas Dublin Book Festival. Zapytany o wybór miejsca akcji odparł, że jego opowiadania są „na tyle uniwersalne, że mogłyby się rozgrywać w każdej stolicy w Europie, a nawet poza nią"2.

1 A.M. Bakalar Polish People are Britain's Invisible Minority, "The Guardian"18.12.2012, http://www.theguardian.com/commentisfree/2012/ dec/18/polish-people-britain-invisible-minority (2.11.2015).

2

D. Zuchowski The New Dubliners by Daniel Zuchowski, "Writing.ie", http://www.writing.ie/tell-your-own-story/the-new-dubliners-by-daniel-zuchowskil (2.11.2015).
Joanna

Kosmalska - mgr, asystent $w$ Zakładzie Literatury i Kultury Brytyjskiej Ut. Zastępca kıerownıka i autorka projektu Poiskaliteratura (e) migracyina wirlandii i Wielkiej Brytanii po 2004 finansowanego przez NCN. Członek zespołu redakcyjnego czasopisma literackiego "Dekadentzya. Ostatnı opublikowała szereg wywiadów z autorami migracy)nymi i artykułów na temat Polaków tworzących na Wyspach Brytyjskich. Kontakt: jkosmalska@unı. lodz.pl 
Wspomniane książki to tylko dwie pozycje z ponad osiemdziesięciu poetyckich, prozatorskich oraz dramatycznych utworów napisanych i opublikowanych po 2004 roku przez polskich autorów, którzy mieszkali bądź nadal mieszkają na Wyspach Brytyjskich ${ }^{3}$. Poniewaz wszystkie te teksty zrodziły się ze zderzenia rodzimego kontekstu pisarzy z obcym, wielokulturowym kontekstem kraju przyjmującego, doskonale ilustrują powstawanie współczesnej europejskiej literatury transnarodowej.

Choć transnarodowość jako długodystansowe podróże, odkrywanie nowych terenów czy nawiązywanie stosunków handlowych sięga korzeniami zamierzchłej historii, kiedy „narodowość” jeszcze nie istniała, to pojawienie się nowych możliwości szybliego i sprawnego przemieszczania się, komunikacji oraz przepływu towarów i usług fundamentalnie zmieniło współczesny świat. W relatywnie krótkim czasie zacieśniły się społeczne, polityczne i ekonomiczne więzi między krajami, wirtualna rzeczywistość Internetu rozwinęła się równolegle do realnego świata, a granice geograficzne zatarły się. Migracje na wielką skalę stały się chlebem powszednim, ale w odróżnieniu od poprzednich pokoleń nowi migranci utrzymują bliskie więzi rodzinne, ekonomiczne, polityczne i religijne z ojczyzną. Jednocześnie integrują się w nowym środowisku szybciej niż poprzednie pokolenia, z większą łatwością nawiązując kontakty w lokalnym społeczeństwie, ale też chętniej przejmując jego wartości i styl bycia".

Gdy mówimy o integracji, nawsuwa się pytanie, co właściwie to słowo znaczy w wieloetnicznym i wielokulturowym kraju, takim jak Wielka Brytania czy współczesna Irlandia. Oznacza ono odnalezienie miejsca - bez względu na to, czy będzie to metropolia, małe miasto czy wieś - gdzie dana osoba może realizować swoje życiowe plany. Kiedy migrant znajdzie juź takie miejsce, staje przed koniecznością poznania kultur, które otaczają go w sąsiedztwie i w środowisku pracy. Innymi słowy, nacisk położony jest na najbliższe otoczenie, bowiem nowo przybyły nie integruje się z całym brytyjskim czy irlandzkim społeczeństwem, ale z lokalną, często mocno etnicznie

3 Pełen spis bibliograficzny utworów będących przedmiotem analizy w artykule jest dostępny na stronie Archiwum wirtualnego, które zostało opracowane w ramach projektu "Polska literatura (e)migracyjna...": archiwum-emigracja.uni.lodz.pl. Stąd w przypisach wymieniam tylko cytowane pozycje.

4 Krótki opis zjawiska transnarodowości i jego implikacji został opracowany m.in. na podstawie książki S. Vertovec Transnationalism, Routledge, New York 2009 i artykułu A. Lima Transnationalism: A New Mode ofImmigrant Integration, The Mauricio Gastón Institute, University of Massachusetts Boston, Boston 2010. 
zróżnicowaną społecznością, w której żyje na co dzień. Dla migranta oznacza to konieczność zapoznania się z wieloma kulturami, a nie - tak jak kiedyś poddanie się jednej historycznie ugruntowanej tradycji. Utrzymując więzi z różnymi społecznościami, zarówno w kraju przyjmującym, jak i rodzinnym, tworzy on wyimaginowany, wirtualny świat, nazywany przez socjologów "transnarodową przestrzenią społeczną"5, a przez krytyków literatury "trzecią przestrzenią". Zachodzą tam procesy interpretacji i łączenia się kultur, k tóre są często określane takimi terminami jak: przekład kulturowy, hybrydyzacja, brikolaż, synkretyzm czy kreolizacja. Zjawiska te znajdują wyraźne odbicie właśnie w literaturze.

Mając to na uwadze, staram się w tym artykule prześledzić, w jaki sposób „nowe” aspekty transnarodowości - a precyzyjnej rzecz ujmując, jak zmiany w transporcie, przełamanie barier hamujących przepływ ludności, cyfryzacja mediów oraz globalizacja relacji ekonomicznych i społecznych ${ }^{7}$ - wpłynęły na współczesną twórczość polskich migrantów, którzy podjęli decyzję o wyjeździe na Wyspy Brytyjskie. Przyglądam się więc, jak obniżenie kosztów podróżowania i otwarcie granic Unii Europejskiej pozwoliło na konfrontację postkomunistycznego Wschodu z wielokulturowym Zachodem. Owo spotkanie doprowadziło bowiem do tego, że poszerzył się obszar, na którym rozgrywają się losy bohaterów; zmienił się charakter opisywanych miejsc; a akcja została przeniesiona do przestrzeni między prawdziwymi i wyimaginowanymi granicami Polski (co podważyło równocześnie nacjonalistyczne i kosmopolityczne paradygmaty). Ta wyobrażona przestrzeń często nakłada się na siebie z cyberprzestrzenią. Kiedy migranci zadomowią się już w nowym miejscu, zaczynają dużo czasu spędzać przed komputerem, a to za sprawą Internetu, który nie tylko umoźliwia im komunikację z najbliższymi, ale także jest źródłem wiadomości z domu i tym samym staje się dla nich miejscem spotkań towarzyskich i oknem na ojczyznę. Takie silne uzależnienie od wirtualnej rzeczywistości wpłynęło na narrację i język utworów migracyjnych, które, jak zobaczymy po głębszej analizie, mają wiele wspólnych cech z blogami,

5 Ang. transnational social fields, termin zaczerpnięty z artykułu P. Levitt i N.G. Schiller Conceptualizing Simultaneity: A Transnational Social Field Perspective on Society, "The International Migration Review" 2004 No. 38/3.

6 H.K. Bhabha używa terminu "trzecia przestrzeń" (ang. the third space) w Miejscach Kultury, przeł. T. Dobrogoszcz, Wydawnictwo UJ, Kraków 2010.

7 Podział na "stare" i „, nowe" aspekty transnarodowości przytoczony za S. Vertovec Transnationalism, S. 14-16. 
portalami informacyjnymi i komunikatorami. Język literacki przekształcił się też pod wpływem naturalnych procesów hybrydyzacji, które przeobraziły dyskurs migrantów w specyficzny żargon pełen anglicyzmów i neologizmów. Dialekt ten, uchwycony przez pisarzy we współczesnej literaturze diaspory, odzwierciedla wymianę międzykulturową, zintensyfikowaną na skutek poakcesyjnych migracji. Siłą dodatkowo ją napędzającą było to, że w ciagu ostatniej dekady zacieśniły się więzi społeczne i ekonomiczne między Polską i Wyspami Brytyjskimi, prowadząc do pojawienia się dwóch istotnych zjawisk: $\mathrm{z}$ jednej strony mamy do czynienia z rosnącym utowarowieniem literatury migracyjnej, z drugiej zaś problematyka w nich poruszana staje się bardziej uniwersalna - co, oprócz wyżej wspomnianych tez, postaram się udowodnić.

Od upadku komunizmu w latach 8o. żadne inne wydarzenie historyczne nie wpłynęło na kształt polskiej literatury tak znacząco, jak wstąpienie Polski do Unii Europejskiej w 2004 roku. Pokolenie Polaków, które doprowadziło do obalenia reżimu komunistycznego, otworzyło granice Europy swoim dzieciom, a wstąpienie naszego kraju w struktury unijne przypieczętowało ten historyczny sukces. To, że migranci mogli opuścić miejsce urodzenia i bez problemu wyjechać do Anglii czy Irlandii, było niezaprzeczalnym dowodem na spełnienie się snu o Polsce jako wolnym kraju europejskim. Dlatego masowe wyjazdy młodych ludzi początkowo nikogo nie martwiły. Nie bez znaczenia było też to, że pod wpływem pączkującego kapitalizmu w latach 90. w Polakach rozwinęła się nieodparta chęć rozwoju. W krótkim czasie wkroczyli oni ze świata, gdzie brakowało podstawowych produktów, do rzeczywistości, w której półki uginały się pod ilością towarów, ale ludziom brakowało środków finansowych, by móc z tej zadziwiającej przemiany korzystać. Społeczeństwo próbowało uzdrowić sytuację, podnosząc swoje kwalifikacje, stąd liczba studentów na uniwersytetach wzrosła prawie pięciokrotnie z 390000 w 1990 roku do 1906 ooo w 2004 roku. Aż w końcu wielu Polaków obrało jako kierunek krótkich wycieczek Zachód, gdzie zetknęli się z zachodnioeuropejskimi realiami i zapragnęli żyć w bardziej liberalnej rzeczywistości. Gdy mimo wytężonych wysiłków nie udało im się tego osiągnąć w raczkującej, źle zarządzanej kapitalistycznej Polsce, coraz częściej podejmowali decyzję o opuszczeniu kraju. Wśród migrantów dużą część stanowiły osoby, których wyjazd był podyktowany długoterminowym brakiem zatrudnienia, ale wielu

8 Ministerstwo Nauki i Szkolnictwa Wyższego Szkolnictwo wyższe w Polsce. Raport, 2013, https:// www.nauka.gov.pl/g2/oryginal/2013_07/0695136d37bd577c8abo3acc5c59a1f6.pdf(2.11.2015). 
ludzi wyruszyło za granicę również, a czasami przede wszystkim, w poszukiwaniu nowoczesności i liberalnych wartości. Wśród nich była Anna Wolf, dramatopisarka i założycielka Polskiego Teatru Irlandia, którą urzekło to, że: „W odróżnieniu od nas, Irlandczycy po prostu żyją na luzie. Nie szukają problemów tam, gdzie ich nie ma. Był to jeden z powodów, dla których się tu przeprowadziłam. W kraju dusiłam się polską mentalnością". Wioletta Grzegorzewska, polska pisarka mieszkająca na Wyspie Wight, dodaje: „Wielu autorów uciekło z kraju ze względu na poglądy, na przykład podróżnicy, autorzy homoseksualni czy feministki"10. Pisarzy przyciągnęła też ciekawość, chcieli bowiem zobaczyć na własne oczy kulturę Zachodu, która przez lata była znakiem buntu przeciwko komunistycznej władzy i oknem na cywilizację, do której Polacy tak bardzo pragnęli przynależeć. Jak pisze Agata Pyzik w książce Poor but Sexy z 2014 roku: „Stoję w kolejce z dziesiątkami rodaków, którzy każdego dnia karmią finansową potęgę Wizzairów, Ryanairów i Easyjetów dzisiejszego świata, ale nie jestem jedną z nich, jestem oszustką: przesadnie wykształconą Polką z klasy średniej, którą uwiódł kulturowy powab Zachodu, a nie przywiodła materialna konieczność"1. Jeśli spojrzymy na wywiady z innymi migracyjnymi pisarzami, okazuje się, że powody, dla których wyjechała Agata Pyzik, nie są tak nietypowe, jak sądzi autorka. Jej słowa odbijają się niczym echo choćby we wspomnieniach Piotra Czerwińskiego, który obecnie mieszka w Dublinie:

Może powinienem zacząć od stwierdzenia, że nie jestem migrantem - jestem ekspatem. Tak określają samych siebie Anglicy, którzy osiedlają się za granicą, by zaznaczyć różnice między sobą a tanią siłą roboczą ze Wschodniej Europy, czyż nie? Cóż, w takim wypadku nie dam im tej satysfakcji i nie będę od nich gorszy. Teź jestem ekspatem! Jeśli chodzi o mój wyjazd do Irlandii, sądzę, że moja historia różni się nieco, od tych opowiadanych przez znaczną więlkszość przybywających tu Polaków. Przede wszystkim, nie musiatem, tylko chciałem wyjechać. Prawdopodobnie jestem jedynym Polakiem, który przywiózł do Irlandii

9 J. Kosmalska, J. Rostek Irish-Polish Cultural Interrelations in Practice: Interviews with Chris Binchy, Piotr Czerwiński, Dermot Bolger, and Anna Wolf "sStudi irlandesi. A Journal of Irish Studies" 2015 No. 5, S. 123 . 1. Kosmalska Czuję się pisarkq polskq z krwi i kości. Rozmowa z Wiolettą Grzegorzewską, „Arterie" $2014 \mathrm{nr} 2$ (19), s. 156.

11 A. Pyzik Poor but Sexy: Culture Clashes in Europe East and West, Zero Books, Croydon 2014, S. 25. 
swoje oszczędności. Zrezygnowałem właśnie z kariery dziennikarskiej, po dwunastu latach pracy w mediach byłem zmęczony i wypalony [...]. Generalnie, potrzebowałem świeżego powiewu, nowego życia. Czegoś innego, tak daleko od świata, w którym żyłem przez te wszystkie lata,jak to tylko możliwe. Z dala od wyścigu szczurów - a proszę mi wierzyć, nie bez przyczyny nazywają to wyścigiem szczurów.

Angielski był jedynym językiem obcym, w którym byłem na tyle biegły, że nie musiałem się za siebie wstydzić, więc wybór był oczywisty, kiedy otworzyli zachodnioeuropejski rynek pracy dla Europejczyków ze Wschodu. W tamtym okresie Anglię omijało się szerokim łukiem. Był to czas ataków terrorystycznych na londyńskie metro. [...] Irlandia wydawała się inna, więc pojechałem do Irlandii. Włożyłem najlepszy garnitur, najlepszy płaszcz, i zabrałem parasolkę z drewnianym uchwytem. Jak widać, moja historia wygląda nieco inaczej... ${ }^{12}$

Pisarze mają świadomość, że ich spojrzenie na migrację to tylko jeden z punktów widzenia, dlatego w swoich utworach przedstawiają bardziej zróżnicowany obraz Polaków mieszkających na Wyspach i naświetlają zazwyczaj dwie skrajne tendencje: jedną zakorzenioną w nacjonalizmie, gdzie migrant stara się odtworzyć swój rodzinny dom za granicą, aby schronić się w nim przed obcością, wrogością nowego miejsca; oraz drugą, wyrastającą na gruncie kosmopolityzmu, gdzie bohater niezwykle ochoczo, czasem nawet zbyt ochoczo, poddaje się konieczności zasymilowania się z nowym otoczeniem.

Pierwszy typ migranta, czyli narodowy radykał, opuszcza kraj głównie z powodów finansowych. Tak jak Radek, infantylny degenerat w powieści Marcina Wojnarowskiego Okrutny idiota albo prywatny zart, lub Krzysztof, obmierzły kierownik Domu Polskiego z opowiadania Michała Wyszkowskiego w zbiorze Na lewej stronie świata, ten typ bohatera cechuje się tym, że bardzo słabo zna angielski, całą energię poświęca na gromadzenie kapitału, który zamierza zabrać z powrotem do Polski, nie interesuje go lokalna kultura, a przed brytyjską rzeczywistością ukrywa się w getcie, które dobrowolnie współtworzy z podobnymi mu ludźmi. Ponieważ jego świat kręci się jedynie wokół polskich sklepów, polskich restauracji, polskich ośrodków społeczno-kulturalnych, polskiego kościoła - słowem, polskich miejsc, idealizuje on rodzime towary i zwyczaje, jednocześnie ostro atakując lokalne wartości i tradycje. To, że postaci te, często, choć nie zawsze, portretowane są w sposób

12 J. Kosmalska, I. Rostek Irish-Polish Cultural Interrelations in Practice..., s. 110. 
satyryczny - obnażający ich niewiedzę, brak manier, małostkowość czy uzależnienia - sugeruje pogardliwy stosunek pisarzy do tego rodzaju migranta. Z kolei na przeciwnym krańcu znajdują się postaci, które z zapałem spychają na bok własną kulturę, robiąc miejsce bogatszej, zachodnioeuropejskiej tradycji. Na kształt Magdy, bohaterki powieści A.M. Bakalar Madame Mephisto, trudniącej się handlem narkotykami, czy Damiana, głównej postaci opowiadania To Be on Time Daniela Żuchowskiego, ten typ migranta nie odczuwa potrzeby przynależności do żadnego miejsca, wręcz przeciwnie: odrzuca wszelkie więzy, które mogłyby go przytrzymywać. Żyjąc w przeświadczeniu, że z łatwością potrafi odnaleźć się w każdym środowisku, gloryfikuje obcość, inność, koloryt lokalnego otoczenia, a jednocześnie nie szczędzi ostrej krytyki światu, który za sobą pozostawił.

Co ciekawe, te dwie postawy nie wykluczają się, ale uzupełniają, a z ich połączenia wyrasta nowa koncepcja migranta, u którego rozwija się transnarodowa tożsamość, rozciągnięta między kosmopolitycznym a nacjonalistycznym biegunem. Tożsamość ta dynamicznie kształtuje się pod wpływem asymilacji z lokalną, wieloetniczną społecznością, ale naturalnie pozostaje też zanurzona w ojczystej kulturze podmiotu. Metaforycznie można ująć to tak, że migrant jedną nogą stoi w kraju urodzenia, a drugą w miejscu, do którego wyjechał. Żyjąc w dwupunktowym układzie odniesienia, korzysta jednocześnie z wiedzy i doświadczenia obu społeczności. Skutkiem ubocznym tego zjawiska jest utrata poczucia przynależności do któregokolwiek z krajów, jakby migracja wiązała się z odcięciem i niezapuszczaniem korzeni, dryfowaniem w wirtualnej transnarodowej przestrzeni. Stąd na powracające pytanie: „Gdzie więc należę?”, pisarze udzielają podobnej odpowiedzi jak Piotr Surmaczyński w Wyspie dreszczowców: „Może do rezerwuaru przechowującego różne pozbawione korzeni stworzenia, które nigdzie nie należą?"'13. Myśl ta powraca na przykład w Singlach, gdzie Piotr Kępski pisze: „Bezprizorny, nie przynależę do żadnego świata"14. Odwołując się do języka fizyki, tożsamość migranta zostaje umiejscowiona w polu grawitacyjnym, gdzie obiektami w przestrzeni, które wywołują zmiany tożsamościowe, są wieloetniczne kultury otaczające migranta. Naturalnie szybkość tych zmian zależy od wieku - im starszy człowiek, tym transformacja przebiega wolniej. W opowiadaniu Wstronę domu Michał Wyszkowski rozróżnia trzy grupy wiekowe: dwudomowcy to „pokolenie emigracyjnych dziadków i babć”, ludzie Made

13 P. Surmaczyński Wyspa Dreszczowców, Novae Res, Gdynia 2014, s. 85.

14 P. Kępski Single, Jir afa Roja, Warszawa 2009, s. 270. 
in Poland, którzy nadal czują mocne przywiązanie do ojczyzny, a przez to dzielą wszystko na pół, „pieniądze, czas, nawet emocje wysyłane do kraju szyblim internetowym łączem"; z kolei do bezdomow ców należą ludzie w wieku średnim, którzy są zbyt młodzi (tj. zbyt liberalni i postępowi), by żyć w Polsce, a za starzy, aby o swojej ojczyźnie zapomnieć i poczuć się w nowym miejscu jak w domu; ostatnia grupa to dzieci integracji europejskiej, , chuligani wolnego przepływu ludzi i myśli", dwudziestolatkowie, którzy Polskę traktują jak dom swoich rodziców lub miejsce wakacyjnych wyjazdów ${ }^{15}$.

To, że migranci mają możliwość szybkiego przemieszczania się między Polską a Wyspami Brytyjskimi i łatwy dostęp do mediów cyfrowych, stworzyło iluzję bliskości, zacierania się politycznych granic, kurczenia się świata. W konsekwencji w migrantach zrodziło się silne poczucie życia w zawieszeniu, w wirtualnej przestrzeni między dwoma światami. W Ziemi wróżek Krystian Ławreniuk porównuje to zjawisko do „przemykania z jednej bajki do drugiej"16, a Wioletta Grzegorzewska w Czasie mew wyznaje: „Na tej wyspie, jak między snami, kręcę się wolno, jestem podwójna..."17. Ta dwoistość egzystencji prowadzi do tego, że migranci tworzą sobie świat wyobrażony w przemieszczonej, płynnej, porowatej przestrzeni wirtualnej, gdzie budują swoją „ojczyznę prywatną", ukształtowaną nie przez wielkie dzieje historyczne wojny, zabory i rewolucje - ale przez ich własne koleje losu. Piotr Czerwiński stara się uchwycić ulotną naturę tego miejsca w Międzynarodzie, gdzie pisze: „Nasz kraj, który może być gdziekolwiek i czymkolwiek. Nasz kraj, którego może nie być. Może Polska to nie państwo. Może to stan umysłu"18. Podobnie Adam Gruchawka dochodzi do wniosku w Butach emigranta, że „ojcowizna to idea"19. Życie migrantów poza granicami kraju wpłynęło na ich postrzeganie ojczyzny, która stała się wytworem wyobraźni, ukształtowanym przez osobiste doświadczenia. Choć jest za wcześnie, by stawiać tezy, że zapanował transnarodowy porządek albo że staliśmy się - jak sugeruje tytuł powieści Grzegorza Kopaczewskiego - członkami Global Nation ${ }^{20}$, to dzięki utworom

15 M. Wyszkowski Na lewej stronie świata, MG, Warszawa 2010, S. 198 - dotyczy wszystkich cytowanych fragmentów z opowiadania Wstronę domu K. Ławreniuk Ziemia wróżek, Fundacja Rozwój, Brzeg 2014, s. 153. W. Grzegorzewska Pamięć Smieny/Smena's Memory, Off-Press, London 2011, s. 101.

P. Czerwiński Międzynaród, Świat Książki, Warszawa 2011, s. 329. 
migracyjnym w polskiej literaturze zaszła wyraźna zmiana: wąską definicję ojczyzny zastąpiło bardziej złożone, globalne, zhybrydyzowane postrzeganie kraju ojczystego.

Odwołując się do terminologii socjologicznej, przepływ kulturowy między centrum (Wielką Brytanią i Irlandią) i peryferiami (ojczyzną polskich migrantów) stał się silnym, dwustronnym procesem i doprowadził do poszerzenia - nakreślenia niejako od nowa - mentalnych granic Polski. W centrum uwagi pisarzy znalazły się kontakty, wymiana i praktyki, które dzieją się ponad granicami państw, niezależnie od politycznych czy geograficznych podziałów, i które sprawiają, że migranci utrzymują bliskie stosunki z kilkoma lokalnymi społecznościami w różnych zakątkach świata równocześnie. W rezultacie autorzy przestali skupiać się głównie na polskim podwórku, a włączyli do swoich rozważań, na znacznie szerszą niż dotychczas skalę, wyspiarskie elementy, takie jak lokalne krajobrazy, wydarzenia czy zwyczaje. Co za tym idzie, w ich utworach pojawiło się wiele zagranicznych miejsc, etnicznie zróźnicowani bohaterowie i zachodnie tradycje, a to wszystko przedstawione - nie z punktu widzenia turystów czy zewnętrznych obserwatorów - ale „od wewnątrz", z perspektywy aktywnych uczestników wydarzeń. Pisarze podkreślają też, jak istotne w podtrzymywaniu więzi z ich krajem rodzinnym są nie tyle działania polityczne czy odwoływanie się do świadomości historycznej, ile tworzenie żywej, społecznie zaangażowanej, eksperymentującej ze środkami przekazu polskiej kultury. Jak zauważa Anna Wolf, ponieważ „obecnie nie musimy walczyć przeciwko reżimowi, nasz patriotyzm objawia się raczej przywiązaniem do kultury"21. Nie ma ona jednak na myśli organizowania folklorystycznych występów w polskich ośrodkach za granicą, ale działalność artystyczną, która z jednej strony pomoże innym narodom zrozumieć Polaków i ich tradycję, a z drugiej poszerzy horyzonty ludzi mieszkających w Polsce. Innymi słowy, Anna Wolf nawołuje do tworzenia transnarodowej literatury, charakteryzującej się wielością miejsc akcji, wchodzącej w interakcję z innymi kulturami i językami, a do tego łączącej w sobie wartości narodowe i kosmopolityczne.

Jeśli spojrzymy na migracyjnych pisarzy, takie transnarodowe utwory - co zresztą wydaje się całkiem naturalne - często powstają w nieograniczonej przestrzeni Internetu. Narratorka Cieni na wrzosowisku Anny Łajkowskiej już na pierwszej stronie powieści wyjawia: „Początkowo chciałam, żeby to był

21 J. Kosmalska, J. Rostek Irish-Polish Cultural Interrelations in Practice..., s. 130. 
blog..."22. Wioletta Grzegorzewska takie pragnienie wcieliła w życie, zakładając blog Pamięć Smieny, gdzie już od wielu lat publikuje obserwacje, które następnie włącza do swojej twórczości. Zapytana o aktywność w Internecie, pisarka przyznaje: „Na początku emigracji dużo publikowałam na portalach warsztatowych, takich jak Nieszuflada, dlatego że była to jedyna ścieżka do polskich czytelników. [...] Z mojego punktu widzenia emigrantom brakuje kontaktu z ludźmi z kraju i szczególnie uaktywniają się na stronach w momencie wyjazdu"23. To, że aktywność Grzegorzewskiej w cyberprzestrzeni znacząco wpłynęła na jej twórczość, staje się jasne, gdy przyjrzymy się jej publikacjom. Tomik poezji Pamięć Smieny/Smena's Memory z 2011 roku nosi dokładnie taki sam tytuł jak blog pisarki, a Notatnik z wyspy, jej silva rerum, zachowuje blogową formę i układ graficzny: podzielony jest na krótkie sekcje-posty, z których każdy oznaczony jest datą. Pamiętnik dokumentuje chronologicznie lata 2006-2012, a więc okres od momentu przyjazdu pisarki do Anglii aż do roku, w którym wydawnictwo e-media opublikowało jej zapiski. Fragmenty Notatnika z wyspy i Pamięci Smieny zostały następnie włączone do Finite Formulae and Theories of Chance, zbioru, który w tłumaczeniu Marka Kazmierskiego, ukazał się nakładem brytyjskiego wydawnictwa Arc Publications. Na okładce jako autorka tomu widnieje Wioletta Greg, pseudonim literacki przyjęty przez Grzegorzewską, kiedy okazało się, że Brytyjczycy nie są w stanie wymówić jej nazwiska. W 2015 roku zbiór znalazł się w finale kanadyjskiego konkursu poetyckiego, gdzie walczył o prestiżową Griffin Poetry Prize.

Podobnie jak Grzegorzewska, Daniel Żuchowski również założył stronę internetową, gdzie przez kilka miesięcy publikował kolejne fragmenty swoich opowiadań. Zwróciły one uwagę wydawców irlandzkiego magazynu literackiego, Writing.ie, którzy zaproponowali, by Żuchowski kontynuował pracę nad zbiorem na ich portalu. Fakt ten odnotowali organizatorzy Dublin Book Festival, jednego z największych wydarzeń literackich w Irlandii. W 2014 roku zaprosili polskiego prozaika, by zaprezentował tam swój debiu tancki tom. Recenzja The New Dubliners ${ }^{24}$ ukazała się w wysokonakładowym,

22 A. Łajkowska Cienie na wrzosowisku, Damidos, Katowice 2013, s. 7.

23 J. Kosmalska Czuję się pisarka polskg z krwi i kości, s. 154.

24 Tytuł książki Daniela Żuchowskiego nawiązuje do słynnego zbioru opowiadań Jamesa Joycéa Dubliners (Dublińczycy) z 1914 roku, w którym autor opisuje życie mieszkańców w stolicy Irlandii. W setną rocznicę wydania książki ukazała się "kontynuacja” opowiadań, przedstawiająca życie współczesnego Dublina, a do jej stworzenia redaktorka tomu Oona Frawley zaprosiła 
opiniotwórczym dzienniku The Irish Times, gdzie Lorraine Courtney oceniła, że „fabuła nie zawsze jest spójna, dlatego funkcjonuje lepiej jako hałaśliwe i barwne uczczenie współczesnego Dublina niż konwencjonalna narracja. Rozpasana i rozkrzyczana, ważna książka, której autor jest doskonale zaznajomiony z doświadczeniami Nowych Irlandczyków"25. Z kolei odwiedzając stronę Jana Krasnowolskiego, możemy śledzić jego postępy nad nową powieścią Wspótczucie dla diabła. Jak zapowiada pisarz, książka będzie powstawała w formie bloga, co pozwoli czytelnikowi śledzić zmiany, a autora zmobilizuje zapewne do regularniejszej pracy nad ukończeniem powieści. Krasnowolski, Żuchowski i Grzegorzewska to tylko troje z wielu autorów, u których doszło do swoistej „elektronizacji” twórczości. Używają oni blogów jako narzędzia pisarskiego, interaktywnej przestrzeni, gdzie zbierają i porząd kują myśli, aby następnie opublikować je w formie książki.

W momencie przejścia z wirtualnej rzeczywistości blogów do namacalnego świata drukarni, widać, jak znaczący wpływ na narracje literackie ma internetowa aktywność pisarzy. Przede wszystkim pierwsze reakcje mogą oni śledzić, gdy książka jest jeszcze w fazie tworzenia, czytelnicy mają bowiem możliwość przesyłania komentarzy e-mailem lub umieszczania ich na stronach internetowych. Zanim więc tekst ukaże się drukiem, często zostaje oceniony przez odbiorców i częściowo przez nich ukształtowany. Z kulturą blogowania wiąże się też etos niezależności: ponieważ autorzy sami tworzą strony, mają nieograniczoną kontrolę nad ich formą i zawartością. Wolność tę zachowują, wydając swoje książki nakładem własnym lub w małych, niezależnych wydawnictwach (takich jak Fox Publishing, Papierowy Motyl, Radwan, Drugie Piętro, Piktor czy Damidos) - co jest typowe dla współczesnej literatury migracyjnej. Kolejnym podobieństwem, jakie łatwo dostrzec między blogami i analizowanymi tekstami, jest ich pamiętnikarski i dziennikarski charakter. Jak podaje Rebecca Blood, etymologia „bloga” sięga korzeniami lat 9o. i wywodzi się od "internetowego pamiętnika" (web journal), który Jorn Barger nazwał „web-logiem" (sieciowym dziennikiem). Od momentu, gdy Peter

uznanych i nagradzanych pisarzy irlandzkich, takich jak Roddy Doyle, Colum McCann, Joseph O'Connor czy Maeve Binchy. Tym sposobem powstał pamiątkowy zbiór opowiadań New Dubliners. Poza odwołaniem do wyżej wspomnianych książek, tytuł tomu Daniela Żuchowskiego The New Dubliners [Nowi Dublińczycy] nawiązuje do politycznie poprawnego terminu The New Irish (Nowi Irlandczycy), którym w latach 1946-1961 określano irlandzkich emigrantów w StanachZjednoczonych, a którego obecnie używa się w odniesieniu do poakcesyjnych migrantów, by zaznaczyć, że stali się oni częścią lokalnego społeczeństwa.

C. Lorraine Bawdy and Boisterous: The New Dubliners, "The Irish Times" 5.07.2014. 
Merholz ogłosił, że będzie wymawiał to słowo jako „wee-blog”, szybko zostało ono skrócone po prostu do „bloga" ${ }^{26}$. W monografii Blogging, Citizenship, and the Future of Media Mark Tremayne zauważa, że dwoma najbardziej popularnymi rodzajami blogów są „sieciowe dzienniki”, gdzie blogerzy opisują osobiste perypetie, oraz „blogi-filtry” (filter blogs), na których autorzy - z nadzieją, że uda im się zmienić sytuację społeczną - komentują bieżące wydarzenia, „filtrując" informacje z innych źródeł. Dlatego ten typ blogów jest często określany jako alternatywny rodzaj dziennikarstwa ${ }^{27}$. Gdy przyjrzymy się książkom migracyjnym, okazuje się, że w około dziewięćdziesięciu procentach przypadków mamy do czynienia z połączeniem tych dwóch rodzajów blogów: wspomnienia Polaków z Anglii i Irlandii poprzeplatane są refleksjami na temat nasilających się migracji i dramatycznej sytuacji w Polsce, a autorzy często odwołują się do przekazów medialnych, zestawiając je z rzeczywistością. Podobnie jak blogerzy, pisarze są najczęściej zaangażowani osobiście w poruszane problemy i opisują je w sposób mocno subiektywny, co skutkuje pierwszoosobową narracją w przeważającej większości blogów i książek migracyjnych, ale także charakterystycznym stylem pisania, trafnie określonym przez Ninę Wakeford i Krisa Cohena jako „spontaniczny i odkrywczy" ${ }^{28}$.

W niektórych książkach, jak choćby w WOT.4 Marii Budacz czy Na lewej stronie świata Michała Wyszkowskiego, znajdziemy nawet podział tekstu na krótkie, tematyczne sekcje, formą przypominające posty. Powszechna tendencja blogowania dyktuje, by wpisy te były ułożone chronologicznie, zgodnie z datą ich opublikowania, i jakby przestrzegając tej reguły, dominująca większość analizowanych pisarzy nie zakłóca chronologii fabuły w swoich narracjach. Co więcej, programy blogowe umożliwiają wykorzystanie wielu środków przekazu, takich jak: tekst, zdjęcia, dźwięk, wideo czy odnośniki do innych stron. Choć możliwość posiłkowania się multimediami w przypadku książek jest naturalnie bardzo ograniczona, to jednak można wychwycić pewne cechy - funkcjonujące na zasadzie hiperlinków - które występują częściej w polskich utworach migracyjnych niz w tekstach powstających w Polsce. Wśród nich moźna wymienić fragmenty rozmów przez Skype'a i telefon,

26 R. Blood weblogs: a history and perspective, "rebecca's pocket" 7.09.2000, http://www.rebeccablood.net/essays/weblog_history.html (2.11.2015). M. Tremayne Introduction: Examining the Blog-Media Relationship, w: Blogging, Citizenship, and the Future of Media, ed. M. Tremayne, Routledge, London 2006, s. X.

28 N. Wakeford, K. Cohen Fieldnotes in Public: Using Blogs for Research, w: The SAGE Handbook of Online Research Methods, ed. N.G. Fielding, R.M. Lee, G. Blank, London 2008, s. 308. 
liczne e-maile, przypisy i słowniki zawierające tłumaczenia z języka angielskiego, dokumentację fotograficzną, cytaty piosenek, recenzje serialu Londyńczycy, a także odniesienia do brytyjskich, irlandzkich i polonijnych przekazów medialnych. Naśladując brytyjski zwyczaj, rzadko jeszcze praktykowany w Polsce, autorzy kręcą też wideoklipy - od amatorskich nagrań, jak filmy Przemysława Kolasińskiego, po profesjonalne zwiastuny, jak materiały filmowe Jarka Sępka czy Marka Kazmierskiego - by promować swoją twórczość w Internecie. Zatem w przypadku wielu utworów migracyjnych proces ich powstania zdaje się zataczać koło: książki tworzone są w przestrzeni wirtualnej, później trafiają do drukarni tylko po to, by powrócić do Internetu, gdzie są promowane i dystrybuowane. Nie powinno więc dziwić, że przy takiej współzależności wirtualnego i realnego świata rozwinęły się liczne, wyżej wspomniane paralele między pisarstwem online i twórczością migracyjiną.

Silna zależność autorów mieszkających za granicą od Internetu wpłynęła też na język literacki. Jakby idąc w ślady użytkowników mediów społecznościowych, dla których nadrzędnym celem jest przekazanie informacji, pisarze skupiają się na naświetleniu głównej akcji i swoich przemyśleń, przedkładając treść nad dbałość o formę, co sprawia, że ich teksty pozbawione są zazwyczaj rozbudowanych, szczegółowych opisów miejsc i bohaterów, a język charakteryzuje się bezpośredniością, kolokwialnością, żartobliwością i prostotą. Relatywnie krótkie zdania, dość ubogie w przymiotniki czy przysłówki, poprzeplatane są za to licznymi neologizmami. Dla przykładu narrator powieści Ireneusza Gębskiego W cieniu Sheratona pracuje jako „kejpis”, czyli pomoc kuchenna (słowo jest akronimem angielskiego zwrotu kitchen porter $[/ \text { kei/+/pi:/+s] })^{29}$, a pracownicy wesołego miasteczka z Ziemi wróżek Krystiana Eawreniuka z upragnieniem czekają na "rain off", czyli dzień wolny od pracy (day off) z powodu opadów deszczu (rain $)^{30}$. Jeśli na wymienione powyżej cechy lingwistyczne spojrzymy poza kontekstem literackim, natychmiast przywodzą one na myśl język komunikatorów sieciowych: Skype’a, Twittera czy Facebooka. Dodatkowo mamy do czynienia z naturalną kreolizacją mowy, występującą u migrantów, gdy przystosowują się oni do życia w innym kręgu językowym. Zupełnie inaczej niż poprzednie pokolenia pisarzy emigracyjnych, którzy w książkach starali się za wszelką cenę zachować "czystość polskiej mowy", współcześni autorzy odzwierciedlają hybrydyczny żargon,

\footnotetext{
29 I. Gębski Wcieniu Sheratona, Warszawska Firma Wydawnicza, Warszawa 2011, S. 3. 
jakim migranci porozumiewają się na co dzień. W teksty wplatają więc m.in. anglicyzmy, hybrydy, kalki, transkrypcje fonetyczne i anglojęzyczne cytaty. Takim dialektem, celowo zresztą przejaskrawionym, posłużył się Piotr Czerwiński, gdy zainspirowany Mechaniczna pomarańcza Anthony'ego Burgessa, pisał powieść Przebiegum życiae, która ukazała się w 2009 roku nakładem Świata Książki:

Zapłacił dwa jurki to the happy peepal from Africa i wyszedł na świeże powietrze, na którym akurat dla odmiany nie padało. Był szczęśliwy, myślał że wszystkie jego problemy przejdą do historii, a on sam rozpocznie nowe życie szybciej niż się spodziewał, w nowym bajobongo mleczno-miodowym świecie ${ }^{31}$. [...] Nie mieli szczęścia z pracą po studiach, ponieważ w Bulandzie najlepszy sposób, żeby zostać politykiem, to nie mieć żadnej szkoły w ogóle, a oni mieli doktoraty. Job w supermarkecie to raczej user-friendly eutanazja niż robota, $\mathrm{z}$ powodu pampers-pisser pensji, więc uznali, że będzie mniej samobójczo, jeżeli pojadą do Anglii, upokarzać się za funty. Oboje byli zerami w dziedzinie języków obcych, ale Grzesiek miał lucka i znalazł job od zaraz. ${ }^{32}$

Pisarz doprawił swoją prozę zapożyczeniami z języków obcych - głównie angielskiego (,happy”, ,user-friendly”,,,job”), ale też czeskiego („sakra”) i arabskiego ("Bulanda” oznacza Polskę w języku arabskim), spolonizowanymi wyrazami angielskimi („lucka”, „dewajsem” czy „jurki” - termin określający walutę euro, który jest powszechnie używany przez migrantów na Wyspach Brytyjskich), polsko-angielskimi złożeniami ("twice-a-tydzień), transkrypcjami fonetycznymi („peepal”,,empe-sree”), kalkami językowymi (,mleczno- miodowy świat”, czyli dosłowne tłumaczenie angielskiego zwrotu „the land of milk and honey”) i neologizmami ("pampers-pisser” jest przymiotnikiem opisującym bardzo niskie płace, a „bajobongo” to określenie Irlandii, które ma przywodzić na myśl egzotyczny raj). Tym samym zebrał w powieści elementy lingwistyczne, z jakimi zetkniemy się, choć w nieco mniejszym natężeniu, we wszystkich współczesnych tekstach migracyjnych.

31 P. Czerwiński Przebiegum życiae czyli kartonowa sieć, Świat Książki, Warszawa 2009, s. 106. Wyróżnienie słów zostało dodane, by naświetlić cechy omawianego dialektu; w oryginalnym tekście wyrazy te nie są pogrubione.

32 Tamże, s. 236. 
Dialekt ten, zręcznie uchwycony przez pisarzy, ilustruje nie tylko narodziny dynamicznie rozwijającego się języka diaspory, ale przede wszystkim międzykulturową wymianę, nabierającą rozpędu pod wpływem ostatnich migracji. Gdy spojrzymy na teksty pisane przez Polaków za granicą, nawet na krótki, wyżej cytowany fragment Przebiegum życiae, wyraźnie widać, jak kultura Zachodu urzekła autorów, rozbudziła w nich chęć spotkania z Innym/ Obcym i pobudziła ich wyobraźnię. Zapewne dlatego w analizowanej grupie badawczej nie było pisarza, który nie wspomniałby o różnicach kulturowych między Polakami a mieszkańcami Wysp Brytyjskich, uwidaczniającymi się praktycznie we wszystkich sferach życia: poczynając od rzeczy błahych, takich jak ruch lewostronny, gąbczasty chleb, dwa kurki w umywalce czy miękka woda, a kończąc na sprawach ogólniejszych, jak choćby mentalność narodowa, relacje damsko-męskie czy etniczne zróżnicowanie społeczeństwa. Michał Wyszkowski sygnalizuje te różnice już na okładce swojej książki, umiejscawiając Anglię, miejsce akcji, Na lewej stronie świata. Dla wielu migrantów bowiem, kiedy wyjechali z relatywnie monoetnicznej Polski za granicę, była to pierwsza okazja, by doświadczyć życia w wielokulturowej metropolii na zachodzie Europy. Stąd pisarze chętnie podejmują się w swoich utworach analizy tego, jak Polacy reagują na kulturową heterogeniczność i jak radzą lub też nie radzą - sobie z uprzedzeniami wobec innych grup etnicznych. $Z$ tego powodu książkowi bohaterowie wynajmują domy, pracują i spędzają czas wolny z przedstawicielami różnych narodowości i często, podobnie zresztą jak w prawdziwym życiu, nawiązują bliższe znajomości z migrantami z innych krajów niż z Brytyjczykami czy Irlandczykami. Za sarkastycznym tonem, po jaki niejednokrotnie sięgają pisarze, kryje się potępienie ksenofobii i pochwała otwartości na inność/obcość. Jarek Sępek poświęca trzysta stron swojej książki W 8o dni dookoła świata (nie wyjeżdżając z Londynu) po to właśnie, by zgłębić i celebrować wielokulturowość Londynu. Pisarz - idąc w ślady Fileasa Fogga, bohatera słynnej powieści Juliusza Verne’a - zakłada się z redaktorem popularnego „Geographical Magazine”, że w ciągu osiemdziesięciu dni uda mu się odnaleźć osiemdziesiąt różnych narodowości, które mieszkają w stolicy Wielkiej Brytanii. Eksperyment ten ma przede wszystkim na celu pokazanie, jak nieocenionym bogactwem jest różnorodność Londynu. Ponieważ książka została opublikowana po polsku i w Polsce, można domniemywać, że od samego początku była pisana z myślą o polskich czytelnikach. Co ciekawe, z ponad sześćdziesięciu migracyjnych pisarzy tworzących w ciągu ostatnich dwunastu lat, do których udało mi się dotrzeć, tylko pięcioro pisze w języku angielskim, mianowicie A.M. Bakalar, Maria Jastrzębska, Wiktor 
Moszczyński, Marek Kazmierski i Daniel Żuchowski. Główną przyczyną takiego stanu rzeczy jest niedostateczna znajomość języka obcego, do której autorzy otwarcie się przyznają, mówiąc, że wolą pozostać w bliższej im przestrzeni języka polskiego. Oznacza to też, że polska kultura nadal jest dominującą częścią ich tożsamości; to przez jej pryzmat postrzegają i opisują świat zewnętrzny.

Członkowie dwóch poprzednich fal emigracyjnych do Anglii - pierwszej w czasie II wojny światowej i drugiej w latach 80., po wprowadzeniu stanu wojennego - pielęgnowali tożsamość narodową, zakładając Domy Polskie. Jak sugeruje nazwa, miały one być namiastką rodzinnego domu, małą ojczyzną tam, gdzie emigrantów pokierował los. W weekendy ośrodki te tętniły życiem, organizując m.in. lekcje polskiego dla dzieci, msze, tańce, wystawy, sztuki czy spotkania z pisarzami. W budynku mieściły się też zazwyczaj restauracja, bar i biblioteka. Tymczasem z punktu widzenia migrantów, którzy zaczęli napływać po 2004 roku, Domy Polskie okazały się czymś w rodzaju odkopanych wehikułów czasu, promujących działalność artystyczną, która miała niewiele wspólnego ze współczesną kulturą w Polsce. Dlatego zamiast zasilić szeregi już istniejących instytucji, nowo przybyli literaci stworzyli mniej formalne grupy artystyczne, takie jak KaMPe, Poezja Londyn, E=Sztuka czy Interaktywny Salon Piszących w Szkocji. Co ciekawe, rolę Domów Polskich częściowo przejęły polskie sklepy, które praktycznie z dnia na dzień pojawiły się wszędzie na Wyspach Brytyjskich. Według portalu uksimple.info w Wielkiej Brytanii działa ich obecnie 319.

Jak sugerują autorzy powieści, kiedy Polak tęskni za domem, wybiera się na zakupy do polskiego sklepu, ponieważ dla części migrantów lekarstwem na nostalgię jest konsumpcjonizm. Dlatego w wielu książkach - np. w Pokoju z widokiem na Dunnes Stores Eukasza Ślipki czy Dublinie, mojej polskiej karmie Magdaleny Orzeł - osobny rozdział został poświęcony roli, jaką polski sklep odgrywa w życiu diaspory. Autorzy opisują, nie stroniąc od ironii, jak miejsca te wspierają nowo przybyłych i krzewią patriotyzm: oprócz sprzedaży polskich towarów pełnią równocześnie rolę agencji pracy i ośrodka kultury, rozpowszechniając informacje o aktualnych ofertach pracy, ale też o polskich koncertach, wystawach czy spotkaniach z pisarzami. Gdy Magdalena Zimny-Louis chciała zbadać, jakie będzie zainteresowanie jej debiutancką powieścią, zostawiła kilka egzemplarzy Emigracji uczuć w pobliskim sklepie w Ipswich, skąd po kilku dniach otrzymała wiadomość, że książka się wyprzedała. Z kolei Kalendarz Easy Ridera Konrada Jaskólskiego, migranta mieszkającego w Anglii, można nabyć w kwiaciarni w Łodzi. Takie współistnienie literackich 
narracji i handlu pokazuje, jak system ekonomiczny wchłania wytwory kultury. Kiedy więc książki migracyjne zaczęły krążyć razem z innymi towarami, stały się integralną częścią materialistycznego świata. W Global Matters Paul Jay słusznie zauważa, że nie jesteśmy już w stanie „wskazać wyraźnej różnicy między wymianami, które mają charakter wyłącznie materialny i zachodzą na rynku towarów, a wymianami, które są czysto symboliczne i zachodzą na rynku kultury" ${ }^{33}$. Przepływ ekonomiczny napędza transfer kulturowy i viceversa.

Taka dwustronna relacja prowadzi do utowarowienia twórczości migracyjnej w dużo większym stopniu, niż jest w przypadku literatury powstającej w Polsce. Tym bardziej że - jak już wspominałam - wiele z analizowanych książek ukazało się nakładem własnym bądź małych, niezależnych wydawnictw, co zmusiło autorów, by wcielili się równocześnie w rolę pisarza, redaktora, agenta i wydawcy. Taka sytuacja doprowadziła m.in. do tego, że przykładali oni dużą wagę do socjologicznej i antropologicznej funkcji swojego tekstu, często zapominając przy tym o jego wymiarze estetycznym. Ich myślą przewodnią i celem nadrzędnym stało się sportretowanie doświadczenia migracyjnego takim, jakie ono „naprawdę" jest. By dotrzeć z tym przekazem do jak najszerszego grona czy telników, autorzy od początku inwestowali dużo czasu i wysiłku w marketing. Na fali tej mody Anna Wendzikowska zaczęła w 2011 roku promować swoją debiutancką powieść 300 poranków w Londynie, a książka - choć minęło już prawie pięć lat - nadal się nie ukazała. To materialistyczne podejście do tworzenia i dystrybucji książek spowodowało, że do Polski napłynęła z zagranicy fala migracyjnych tekstów, które, mimo że mają małą wartość estetyczną, to poruszają jednak ważkie społecznie i kulturowo tematy. Dlatego, choć literacko pozostawiają wiele - a czasami nawet bardzo wiele - do życzenia, to znajdziemy w nich opis ważnego okresu w polskiej historii współczesnej, w którym dochodzi m.in. do: redefinicji znaczenia narodowości, ojczyzny i patriotyzmu, gwattownej dekonstrukcji starych i ukonstytuowania się nowych stereotypów, transformacji młodych ludzi w europejskich obywateli i powstawania transnarodowej kultury.

Choć kulturę tę migranci tworzą - głównie ze względu na odległość geograficzną - niejako w odosobnieniu, równolegle do działalności artystycznej w Polsce, to jest ona silnie z nią powiązana. Autorzy utrzymują więzi ze

33 P. lay Global Matters: The Transnational Turn in Literary Studies, Cornell University Press, New York 2010, S. 56. 
środowiskiem, które zostawili w kraju, biorąc udział w polskich inicjatywach literackich i organizując wydarzenia we współpracy z pisarzami na stałe mieszkającymi w Polsce. By odwołać się do przykładu: Tomasz Mielcarek, który osiem lat temu przeprowadził się do Anglii, uczestniczył od tego czasu w konkursach w Polsce i zdobył wiele nagród, w tym pierwsze miejsce w Ogólnopolskim Konkursie Poetyckim im. Jacka Bierezina w 2013 roku. Dzięki temu wydał swój debiutancki (dwujęzyczny, co symptomatyczne) tom wierszy Obecność/Presence. Z kolei Marek Kazmierski założył w 2010 roku niezależne wydawnictwo OFF-PRESS w Londynie, wokół którego zgromadził polskich i migracyjnych autorów, a ich współpraca zaowocowała unikatowymi antologiami, takimi jak pięknie wydany, ręcznie złożony, bilingwalny tom poetycki Free Over Blood. Obecnie KaMPe w Londynie i Dom Literatury w Łodzi zastanawiają się nad połączeniem sił i zorganizowaniem w obu miastach kolejnej edycji festiwalu Puls Literatury. Dzięki tej wielomiejscowej współpracy polska literatura częściej „podróżuje” - jest prezentowana i interpretowana w nowych, wielokulturowych kontekstach, tym bardziej że organizatorzy dokładają wszelkich starań, by w te działania angażować lokalnych mieszkańców. Tymczasem autorzy, zdając sobie sprawę, że grono odbiorców może być bardzo zróżnicowane etnicznie, dobierają tak tematy i sposób ich prezentacji, by każdy uczestnik, widz, czytelnik mógł w jakiś sposób się do nich odnieść. Tym samym historyczne wydarzenia i osobiste doświadczenia prezentowane są w bardziej uniwersalnej odsłonie.

Do tego, że polska literatura nabiera uniwersalnych właściwości, przyczyniają się teź literackie inicjatywy mające na celu nawiązywanie współpracy międzynarodowej. Jedną z nich jest The Enemies Project [Wrogowie], przedsięwzięcie, które w 2010 roku zapoczątkował brytyjski poeta SJ Fowler. Jak czytamy na jego stronie: „Projekt ten w takim samym stopniu spogląda ponad narody, języki, płeć i tożsamość etniczną, co ponad formy artystyczne i style w poezji. Jest zwieńczeniem poszukiwań tego, jaką rolę i zadania ma poeta XXI wieku, i jak się one zmieniły wraz z nowymi środkami komunikacji, językiem, technologią i obowiązkami kuratorów" ${ }^{34}$. W ramach tego programu poeci dobierani są w pary, aby wspólnie zmierzyć się z zadaniem polegającym na napisaniu wierszy, a następnie zaprezentowaniu ich podczas specjalnie zorganizowanego wieczoru poetyckiego. Do tej pory odbyły się

34 SI Fowler The Enemies project - www.theenemiesproject.com, http://www.stevenjfowler. com/\#/the-enemies-project/ (2.11.2015). 
dwie edycje, w których polscy poeci (wśród nich wielu migrantów, jak choćby Tomasz Mielcarek, Grzegorz Wróblewski i Piotr Gwiazda) współpracowali z brytyjskimi kolegami po fachu, a następnie wyniki tej kooperacji - wiersze w języku angielskim, zaprezentowali w londyńskim Rich Mix Arts Centre. W podobnym formacie utrzymany jest maraton pisarski Once Upon a Deadline [Był sobie termin], przedsięwzięcie zainicjowane przez australijskiego pisarza i producenta filmowego Roberta Maca, którego formułę wykorzystali organizatorzy Festiwalu Sztuki Polskiej w Southend-on-Sea w 2011 roku. Polscy pisarze (wśród nich znowu liczna grupa migrantów, a w niej Piotr Czerwiński, Kajetan Herdyński i Wioletta Grzegorzewska) zostali połączeni w pary z brytyjskimi autorami, z którymi udali się w podróż po festiwalowym mieście, aby stworzyć w języku angielskim opowiadanie liczące 1500 słów i wieczorem, tego samego dnia, odczytać je na zorganizowanym w tym celu spotkaniu w Clifftown Studios na uniwersytecie w Essex. Następnie teksty zostały zebrane i opublikowane przez OFF-PRESS. Podobną wymianę zorganizowano dla brytyjskich prozaików, którzy, rok później, ukończyli pisarski maraton w Gdańsku.

W takich transnarodowych projektach, jak opisane powyżej, literackie narracje podlegają kulturowemu i językowemu przekładowi już w momencie, gdy powstają. Pisarze zostają wyrwani ze znajomego otoczenia i ulokowani w obcym miejscu, gdzie mają się z tą innością/obcością zmierzyć, włączyć ją do swojego systemu kulturowego i wykorzystać do stworzenia niesztampowego tekstu. Stoi więc przed nimi zadanie, by elementy, które są obce, przywłaszczyć, zneutralizować, przetworzyć i uformować od nowa tak, by wydawały się one równocześnie rodzime i obce; a to jeszcze nie koniec, bowiem efekt tej pracy muszą wyrazić w języku, który nie jest ich językiem ojczystym. Jak przyznaje Paweł Gawroński, jeden z uczestników maratonu Once Upon a Deadline: „To jest bardzo dziwne doświadczenie, kiedy wiesz, że masz bogate słownictwo w języku ojczystym, a później znajdujesz się w kraju, gdzie tracisz największy atut, jaki kiedykolwiek miałeś. Nagle znika, a ty masz dwie możliwości: albo rzucisz się z mostu, albo zaczniesz odkrywać nowe właściwości języka"35. Właściwości, które wnoszą powiew świeżości do stylu pisania, a powstają jako „efekt uboczny" przekładu, kiedy parafrazujemy, przekształcamy, modelujemy język, by oryginalną myśl wyrazić w obcojęzycznych słowach.

35

Cytat pochodzi z filmu promującego zbiór opowiadań Once Upon a Deadline, który jest dostępny na stronie wydawnictwa OFF-PRESS: http://off-press.org/main/books/once-upon-a-deadline/ (2.11.2015). 
W procesie tym oba języki - ojczysty i obcy - wchodzą w interakcję, podczas której każdy z nich wnosi swoje środki wyrazu, dzięki czemu zyskuje się pełniejszy i mniej konwencjonalny opis rzeczywistości. W przypadku narracji powstających w transnarodowej przestrzeni pisarz jest od samego początku umiejscowiony między narodami, językami, kulturami, historiami i wartościami, co daje mu mocne podwaliny, by tworzyć zróżnicowaną, wielowymiarową i hybrydyczną literaturę. Tym bardziej że coraz częściej utwory literackie stają się integralną składową szerzej zakrojonych inicjatyw artystycznych, jak choćby w czasie festiwali, gdzie teksty literackie prezentuje się niejako obok, razem z lub na tle wystaw sztuki, koncertów, przedstawień teatralnych czy projekcji filmowych. Możemy więc mówić o swoistej kreacji artystycznej, a nie wyłącznie literackiej. Takie połączenie różnych dziedzin sztuki autorzy stosują też podczas spotkań promocyjnych. By posłużyć się przykładem: w Birmingham na wydarzeniu promującym Pięknych ludzi, antologię wierszy migracyjnych pod redakcją Adama Siemieńczyka, autorzy recytowali swoje utwory, a w tle puszczano muzykę lub animację filmową. Nie zabrakło też teatralnych inscenizacji wierszy. Trudno nie zauważyć, jaki potencjał niesie ze sobą taka eklektyczna forma podawcza, do tego jeszcze literatury tworzonej w przestrzeni transnarodowej: aliaż języków, kultur i dziedzin sztuki przeciera szlaki nowym formom, stylom i tematom literackim.

Biorąc pod uwagę, że na rynku polskim wydaje się coraz więcej książek, które wychodzą spod pióra migrantów, a tym samym powstają poza granicami Polski, możemy zaryzykować stwierdzenie, że jesteśmy świadkami transnarodowego zwrotu w polskiej literaturze. Czym się on objawia? Otóż właśnie tym - co, mam nadzieję, udało mi się w tym artykule pokazać - że dzięki akcesji naszego kraju do struktur unijnych i tanim lotom polskie teksty tworzone są obecnie w wieloetnicznych przestrzeniach geograficznych, historycznych, kulturowych i językowych; dlatego funkcjonują w różnych systemach społecznych i literackich równocześnie, a więc w odniesieniu do nich powinny być interpretowane. Świadczy o tym choćby zainteresowanie, jakie książki polskich migrantów budzą wśród zagranicznych środowisk literackich i akademickich, czego dowodem jest np. wydana w 2011 roku w Niemczech monografia Contemporary Polish Migrant Culture and Literature in Germany, Ireland and the UK [Współczesna polska kultura i literatura migracyjna w Niemczech, Irlandii i Wielkiej Brytanii] pod redakcją Joanny Rostek i Dirka Uffelmanna. Nikt, kto podejmie się analizy migracyjnych narracji, nie powinien też zapomnieć o istotnej roli, jaką odgrywa Internet w procesie ich powstawania, a więc o tym, jak komunikacja wirtualna i publikacje online wpływają na 
formę i język tekstu. Co więcej, warto przyjrzeć się temu, w jaki sposób bliższe ekonomiczne i społeczne relacje między Polską i krajami Europy Zachodniej stały się przyczynkiem do tego, by pojawily się nowe sposoby tworzenia literatury (w ramach transnarodowych projektów), promowania jej (za pomocą łączenia artystycznych środków wyrazu) i dystrybucji (przez polskie sklepy, wydawnictwa i grupy artystyczne działające za granica). Jeśli podejmując się interpretacji utworów migracyjnych, pominiemy wyżej wspomniane aspekty, to ich przesłanie i wartość zostaną zubożone, zniekształcone, a nawet niezrozumiane. Każdy więc, kto zasiądzie do analitycznej lektury owych książek, będzie poniekąd zmuszony, żeby włączyć te perspektywy do obecnych modeli interpretacyjnych. W przypadku niektórych utworów dostrzeże też konieczność, by - zamiast na estetycznych wartościach - uwagę skupić na społecznych i antropologicznych funkcjach omawianych tekstów: a konkretniej na tym, jak autorzy łączą różne miejsca i narodowości, jak analizują skutki nakładających się na siebie procesów migracyjnych i globalizacyjnych, jak podchodzą do zagadnienia traumy i pamięci, wreszcie, jak starają się uchwycić nowe doświadczenia i - wyrastającą na ich gruncie - transnarodową tożsamość. Wśród tekstów, których jakość artystyczna może nie do końca zachwyca, znajdziemy też białe kruki, jak choćby Guguły Wioletty Grzegorzewskiej czy Angole Ewy Winnickiej, obie książki były nominowane do nagrody Nike w 2015 roku. Takich przykładów jest zdecydowanie więcej i, miejmy nadzieję, że z roku na rok będzie ich przybywać. 


\section{Abstract}

\section{Joanna Kosmalska}

UNIVERSITYOF ŁóDŹ

Writings by Poles in the UK and Ireland: The Transnational Turn in Polish Literature

The article refers to a selection from over 80 books of poetry, prose and drama published since 2004 by Polish authors who have lived in the UK and Ireland. Kosmalska focuses on how the'new' aspects of transnationalism (advances in transportation, the breaking down of barriers to the flows of people, development of electronic media, and globalization of economic and social relationships) have influenced writing by Polish migrants. The texts in this corpus were conceived from the clash between the writers' national context and other, alien contexts, and they illustrate how the driving forces of transnationalism have shaped contemporary Polish literature.

\section{Keywords}

transnational literature, migration, electronic writing, intercultural exchanges, linguistic hybridity 